$\underline{\text { Note }}$

\title{
Reexamination of the Bactericidal Activity of Chlorhexidine Digluconate against Pseudomonas aeruginosa
}

\author{
SHIGERU AKIYAMA ${ }^{1 *}$, MASAE NISHIYAMA ${ }^{2}$, AND SUSUMU FUJIMOTO ${ }^{3}$ \\ 'School of Allied Health Sciences, ${ }^{2}$ School of Hygienic Sciences, and ${ }^{3}$ School of Medicine, \\ Kitasato University, 1-15-1 Kitasato Sagamihara, Kanagawa 228, Japan
}

Rceived 28 November 1996/Accepted 21 May 1997

\begin{abstract}
In our study, we attempted to confirm a paradoxical effect of chlorhexidine digluconate (CHG). Two test procedures, the phenol coefficient (PC) method based on AOAC and its modified method were used. The cell concentration of test strains, Pseudomonas aeruginosa NCTC 7244, $P$. aeruginosa IFO 3445 and some clinically isolated strains were prepared at $10^{4}$ $10^{9} \mathrm{cells} / \mathrm{ml}$. According to the PC method based on AOAC, 1/800-1/1200 was the greatest dilution rate at which $5 \%(\mathrm{w} / \mathrm{v})$ CHG was able to kill $10^{9} \mathrm{cells} / \mathrm{ml}$ of $P$. aeruginosa by contact in 10 $\mathrm{min}$, and 1/10000-1/12000 was the greatest dilution rate in case of $10^{4}$ cells $/ \mathrm{ml}$. Increasing concentrations of CHG to kill $P$. aeruginosa were required as the viable counts of the organism increased. By the modified PC method, when undiluted 5\% (w/v) CHG was added to the 10' cells $/ \mathrm{ml}$ bacterial suspension, the organisms were killed in 4 or $5 \mathrm{~min}$, and those in the $10^{4}$ cells $/ \mathrm{ml}$ suspension were killed within $30 \mathrm{~s}$. Therefore, we could not confirm the paradoxical effect of slime production by $\boldsymbol{P}$. aeruginosa as a phenomenon due to the bactericidal activity of CHG.
\end{abstract}

Key words : Chlorhexidine/Bactericidal activity/Pseudomonas aeruginosa.

Disinfectants play an important role in the control of infection in the hospital. Chlorhexidine digluconate $(\mathrm{CHG})$ is a widely used disinfectant which is used to disinfect not only the skin but also medical treatment apparatuses and the hospital environment as well. $\mathrm{CHG}$ is able to kill many kinds of bacteria other than Mycobacterium tuberculosis and those in the form of bacterial spores. However, it is known that a certain species of Pseudomonas has resistance to $\mathrm{CHG}$ (Namba et al., 1985). In addition, there are some reports of a peculiar and specific phenomenon in the bactericidal activity of $\mathrm{CHG}$ against $P$. aeruginosa (Muto et al.,1984; Tsuji et al., 1986). To kill $P$. aeruginosa with $\mathrm{CHG}$, it would seem that larger bacterial concentrations would require stronger solutions of $\mathrm{CHG}$, or longer contact times in the case of the same $\mathrm{CHG}$ concentrations, for $\mathrm{CHG}$ to show its bactericidal effectiveness. We should reexamine the usage of

*Corresponding author. Tel : +81-427-78-8074, Fax : + 81-427-78-8214.
CHG if the specific phenomenon involving $P$. aeruginosa is always observed. Then, we examined the bactericidal activity of $\mathrm{CHG}$ against $P$. aeruginosa by using two kinds of bactericidal test methods, which are called the customary PC method (AOAC, 1984) and the modified PC method which had been used when the specific phenomenon was first observed (Goto and Tsuji, 1980).

For the experiment 13 strains were used. Of these, there were two standard strains (NCTC 7244 and IFO 3445 ) and 11 strains isolated from clinical materials at the medical laboratory of Kitasato University Hospital, and all strains had the ability to produce slime substance. 5\% (w/v) Hibitane solution(Lot no. ESO 58) was used as the CHG preparation.

The bactericidal effect of $\mathrm{CHG}$ against $P$. aeruginosa was examined at $20^{\circ} \mathrm{C}$ by using $P$. aeruginosa NCTC 7244 which had an adjusted viable count. The viable count of the bacterial suspension for the modified PC method was adjusted to $10^{4}, 10^{5}, 10^{6}$ and $10^{7}$ cells $/ \mathrm{ml}$. The bactericidal effects of diluted $\mathrm{CHG}$ 
against these different viable counts were compared at the time when no growth of the organism was seen. At each cell concentration $\left(10^{4}, 10^{5}, 10^{6}\right.$ and $10^{7}$ cells $/ \mathrm{ml}$ ), $P$. aeruginosa NCTC 7244 could not be killed in 15 min by the disinfectant diluted to 5 times. The diluted $\mathrm{CHG}$ became the usual usage concentration (1:50) after being mixed with a bacterial suspension. This result was the same in the solution in which $5 \%(\mathrm{w} / \mathrm{v}) \mathrm{CHG}$ solution was diluted to two times. The disinfectant diluted to $1 / 15$ could kill $P$. aeruginosa at $10^{4}$ cells $/ \mathrm{ml}$ in 5 min after being mixed with a bacterial suspension, though it was not able to kill the bacteria at $10^{5}$ cells $/ \mathrm{ml}$ or greater even in $15 \mathrm{~min}$. Bactericidal effects were seen by $5 \%(\mathrm{w} / \mathrm{v}) \mathrm{CHG}$ solution in 4 or 5 min against the $10^{7}$ cells $/ \mathrm{ml}$ in one min against the $10^{6}$ cells $/ \mathrm{ml}$ suspension, in half of a minute to one min against the $10^{5}$ cells $/ \mathrm{ml}$ suspension, and within $30 \mathrm{sec}$ against the $10^{4} \mathrm{cells} / \mathrm{ml}$ cell concentration (Table 1). P. aeruginosa with low viable counts was killed by $\mathrm{CHG}$ in a short contact time compared with the time needed to kill high viable counts. That is, $\mathrm{CHG}$ needed a long contact time to kill $P$. aeruginosa with a high viable count.

TABLE 1. Relationship between the cell concentration of the test strain Pseudomonas aeruginosa (NCTC 7244) and the time in min for the diluted $5 \%(\mathrm{w} / \mathrm{V})$ chlorhexidine digluconate to show bactericidal effects as found by the modified PC method.

\begin{tabular}{cccccc}
\hline \multirow{2}{*}{$\begin{array}{c}\text { Cell concn } \\
\text { (cells/ml) }\end{array}$} & \multicolumn{5}{c}{ Dilution rate $(\times 1)$} \\
\cline { 2 - 6 } & 10 & 15 & 20 & 25 & 50 \\
\hline $10^{7}$ & $4-5$ & $>15$ & $>15$ & $>15$ & $>15$ \\
$10^{6}$ & 1 & $>15$ & $>15$ & $>15$ & $>15$ \\
$10^{5}$ & $0.5-1$ & $>15$ & $>15$ & $>15$ & $>15$ \\
$10^{4}$ & 0.5 & $3-5$ & $>15$ & $>15$ & $>15$ \\
\hline
\end{tabular}

On one hand, the viable counts of cultured broth for the PC test method based on AOAC were adjusted to $10^{4}, 10^{5}, 10^{6}, 10^{7}, 10^{8}$ and $10^{9}$ cells $/ \mathrm{ml}$ each. The greatest dilution rate of $5 \%(\mathrm{w} / \mathrm{v}) \mathrm{CHG}$ solution which was able to kill $10^{9}$ cells $/ \mathrm{ml}$ of $P$. aeruginosa NCTC 7244 after contact for 10 min was $1 / 1200$, and $1 / 2000$ in case of $10^{8}$ cells $/ \mathrm{ml}, 1 / 3000$ in case of $10^{7}$ cells $/ \mathrm{ml}, 1 / 5000$ in case of $10^{6}$ cells $/ \mathrm{ml}, 1 / 8000$ in case of $10^{5}$ cells $/ \mathrm{ml}$ and $1 / 10000$ in case of $10^{4}$ cells $/ \mathrm{ml}$ (Table 2). The concentration of $\mathrm{CHG}$ which could kill $P$. aeruginosa NCTC 7244 when the bactericidal time is fixed increased as the viable count of organism increased.

The bactericidal time of $\mathrm{CHG}$ was examined by the modified PC method using 11 strains of $P$. aeruginosa which were isolated from clinical materials. When $5 \%$ (w/v) CHG solution was added to bacterial suspension made so that the viable count was adjusted to $10^{7}$ cells $/ \mathrm{ml}$, no strain was killed after treatment for $15 \mathrm{~min}$. When this solution was added to the $10^{4}$ cells $/ \mathrm{ml}$ bacterial suspension, there were 6 strains which were killed with 5 min of treatment. However, 4 strains were not killed even with treatment for $15 \mathrm{~min}$ (Table 3).

With the PC test based on AOAC, the greatest dilution rate of $5 \%(\mathrm{w} / \mathrm{v}) \mathrm{CHG}$ solution which was able to kill $10^{8}$ cells $/ \mathrm{ml}$ of test organisms was from $1 / 400$ to $1 / 1200$, and differences in effective dilution rates of as many as 3 times existed for the different strains used. Bactericidal effects against $10^{6}$ cells $/ \mathrm{ml}$ of organisms were seen with dilutions of $1 / 4000$ to $1 /$ 8000 , and in case of $10^{4}$ cells $/ \mathrm{ml}$ they were seen with dilution of $1 / 8000$ to $1 / 12000$ (Table 4). Differences in the resistance of $P$. aeruginosa isolated from clinical materials against $\mathrm{CHG}$ did not appear in an obvious manner. However, large viable counts of $P$. aeruginosa were killed by high concentrations of $\mathrm{CHG}$, and small viable counts were killed by low concentrations of $\mathrm{CHG}$.

The phenol coefficient has been generally used to compare the bactericidal activity of the disinfectant. However, the phenol coefficient method has been heavily criticized. For example, Goto and Tsuji (1980) have pointed out four matters of concern regarding the PC method. These four problems were that the species of test strain must be limited, that it is not easy to understand on practical use dilution, that it should be possible to display the dilution rate of the disinfectant accurately, and that for some disinfectants the bactericidal activity decreases remarkably by using the cultured broth as it is. Therefore, some test methods have been designed (Goto and Tsuji, 1980; Jono et al., 1985). One such method is the modified PC method which had been used when the paradoxical bactericidal phenomenon was found, and is the method used in this experiment. The bactericidal activity of $\mathrm{CHG}$ was first reportd by Davies (Davies et al., 1954), since then, many research reports concerning the bactericidal activity of $\mathrm{CHG}$ have been published. In 1984, it was reported by Muto (1984) that the special bactericidal phenomenon of $\mathrm{CHG}$ against $P$. aeruginosa was due to slime production by $P$. aeruginosa. Moreover, in 1986, it was concluded by Tsuji et al. (1986) that the DNA in the slime produced by $P$. aeruginosa at high cell concentrations increased the sensitivity of the organism to $\mathrm{CHG}$. It had already been known that $P$. aeruginosa produces a slime substance in liquid media (Haynes, 1951). However, this specific bactericidal phenomenon has not been confirmed by other researchers. Then, the 
TABLE 2. Effect of the cell concentration of Pseudomonas aeruginosa (NCTC 7244) on the bactericidal activity of 5\% $(\mathrm{w} / \mathrm{v})$ chlorhexidine digluconate as found by the PC method based on $\mathrm{AOAC}$ at $20^{\circ} \mathrm{C}$.

\begin{tabular}{|c|c|c|c|c|c|c|c|c|c|c|c|c|c|c|c|c|c|c|}
\hline \multirow{2}{*}{$\begin{array}{l}\text { Cell concn } \\
\text { (cells/ml) }\end{array}$} & \multirow{2}{*}{$\begin{array}{l}\text { Time } \\
(\min )\end{array}$} & \multicolumn{17}{|c|}{ Dilution rate $(\times 100)$} \\
\hline & & 4 & 8 & 10 & 12 & 15 & 16 & 20 & 30 & 40 & 50 & 60 & 70 & 80 & 100 & 120 & 140 & 200 \\
\hline \multirow[t]{4}{*}{$10^{9}$} & 2.5 & - & + & $*$ & + & $*$ & + & + & $*$ & $*$ & $*$ & $*$ & $*$ & * & $*$ & $*$ & * & $*$ \\
\hline & 5.0 & - & - & $*$ & + & $*$ & + & + & $*$ & $*$ & $*$ & $*$ & $*$ & $*$ & * & $*$ & $*$ & $*$ \\
\hline & 10.0 & - & - & $*$ & - & $*$ & + & + & $*$ & $*$ & $*$ & $*$ & $*$ & $*$ & $*$ & * & $*$ & $*$ \\
\hline & 15.0 & - & - & $*$ & - & $*$ & - & + & $*$ & $*$ & $*$ & $*$ & $*$ & $*$ & $*$ & $*$ & * & $*$ \\
\hline \multirow[t]{4}{*}{$10^{8}$} & 2.5 & $*$ & $*$ & + & * & + & $*$ & + & + & + & $*$ & $*$ & $*$ & $*$ & $*$ & $*$ & $*$ & $*$ \\
\hline & 5.0 & $*$ & $*$ & - & $*$ & - & $*$ & + & + & + & $*$ & $*$ & $*$ & $*$ & $*$ & $*$ & * & $*$ \\
\hline & 10.0 & $*$ & $*$ & - & * & - & $*$ & - & + & + & $*$ & $*$ & $*$ & $*$ & * & * & * & $*$ \\
\hline & 15.0 & $*$ & $*$ & - & $*$ & - & $*$ & - & - & + & $*$ & $*$ & $*$ & $*$ & $*$ & $*$ & $*$ & $*$ \\
\hline \multirow[t]{4}{*}{$10^{7}$} & 2.5 & $*$ & $*$ & + & $*$ & $*$ & * & + & + & + & + & $*$ & $*$ & $*$ & * & $*$ & $*$ & $*$ \\
\hline & 5.0 & $*$ & $*$ & - & $*$ & $*$ & $*$ & - & + & + & + & $*$ & $*$ & $*$ & $*$ & $*$ & $*$ & $*$ \\
\hline & 10.0 & $*$ & $*$ & - & $*$ & $*$ & $*$ & - & - & + & + & $*$ & $*$ & $*$ & $*$ & $*$ & * & $*$ \\
\hline & 15.0 & $*$ & $*$ & - & $*$ & $*$ & $*$ & - & - & - & + & $*$ & $*$ & $*$ & $*$ & $*$ & $*$ & $*$ \\
\hline \multirow[t]{4}{*}{$10^{6}$} & 2.5 & $*$ & $*$ & $*$ & $*$ & $*$ & $*$ & $*$ & - & + & + & + & + & $*$ & * & $*$ & $*$ & $*$ \\
\hline & 5.0 & $*$ & $*$ & $*$ & * & $*$ & $*$ & $*$ & - & - & + & + & + & $*$ & $*$ & $*$ & * & $*$ \\
\hline & 10.0 & $*$ & $*$ & $*$ & $*$ & $*$ & $*$ & $*$ & - & - & - & + & + & $*$ & $*$ & * & $*$ & $*$ \\
\hline & 15.0 & $*$ & $*$ & $*$ & $*$ & $*$ & $*$ & $*$ & - & - & - & - & + & $*$ & $*$ & $*$ & $*$ & $*$ \\
\hline \multirow[t]{4}{*}{$10^{5}$} & 2.5 & $*$ & $*$ & $*$ & $*$ & $*$ & $*$ & $*$ & $*$ & - & * & + & $*$ & + & + & + & $*$ & $*$ \\
\hline & 5.0 & $*$ & $*$ & $*$ & $*$ & $*$ & $*$ & $*$ & $*$ & - & $*$ & - & $*$ & + & + & + & $*$ & $*$ \\
\hline & 10.0 & $*$ & $*$ & $*$ & * & $*$ & $*$ & $*$ & $*$ & - & $*$ & - & $*$ & - & + & + & $*$ & $*$ \\
\hline & 15.0 & $*$ & $*$ & $*$ & $*$ & $*$ & $*$ & $*$ & $*$ & - & $*$ & - & $*$ & - & - & + & * & $*$ \\
\hline \multirow[t]{4}{*}{$10^{4}$} & 2.5 & $*$ & $*$ & $*$ & $*$ & $*$ & * & $*$ & $*$ & $*$ & $*$ & - & * & + & + & $*$ & + & + \\
\hline & 5.0 & $*$ & $*$ & $*$ & * & * & * & $*$ & $*$ & $*$ & $*$ & - & * & - & + & $*$ & + & + \\
\hline & 10.0 & $*$ & $*$ & $*$ & * & $*$ & $*$ & $*$ & $*$ & $*$ & $*$ & - & * & - & - & $*$ & + & + \\
\hline & 15.0 & $*$ & $*$ & $*$ & * & $*$ & $*$ & $*$ & $*$ & $*$ & $*$ & - & $*$ & - & - & $*$ & - & + \\
\hline
\end{tabular}

+, Growth; -, no growth. *, Not tested.

TABLE 3. Time needed for bactericidal effects of $5 \%(\mathrm{~W} / \mathrm{v})$ chlorhexidine digluconate to be seen against clinical isolated strains of Pseudomonas aeruginosa according to the modified PC method.

\begin{tabular}{|c|c|c|c|c|c|}
\hline \multirow{2}{*}{$\begin{array}{c}\text { Strain } \\
\text { no. }\end{array}$} & \multicolumn{2}{|c|}{ Cells per ml } & \multirow{2}{*}{$\begin{array}{c}\text { Strain } \\
\text { no. }\end{array}$} & \multicolumn{2}{|c|}{ Cells per ml } \\
\hline & $10^{7}$ & $10^{4}$ & & $10^{7}$ & $10^{4}$ \\
\hline 2589 & $>15$ & $>15$ & 2879 & $>15$ & 4 \\
\hline 2656 & $>15$ & 2 & 2882 & $>15$ & $\geqq 15$ \\
\hline 2739 & $>15$ & 1 & 2892 & $>15$ & 15 \\
\hline 2740 & $>15$ & 2 & 2911 & $>15$ & 1 \\
\hline 2849 & $>15$ & 1 & 3012 & $>15$ & $>15$ \\
\hline 2853 & $>15$ & $>15$ & & & \\
\hline
\end{tabular}

reconfirmation was atetempted there by using two test methods: a PC method based on AOAC and the modified PC method by which had been used when the specific bactericidal phenomenon was found. As a result, the differences in sensitivity of $P$. aeruginosa to $\mathrm{CHG}$ appeared according to the test strains regardless of which examination method was used, but it was not possible to reconfirm the specific bactericidal phenomenon of $\mathrm{CHG}$ against the organism, since $\mathrm{CHG}$ needed a long time to kill high concentrations of the organism and a short time to kill low cell concentrations. Because the specific bactericidal phenomenon of $\mathrm{CHG}$ had not been reproduced despite using strains isolated not only from standard strains (NCTC 7244, IFO 3445) but also from clinical materials, we were unable to examine the action of DNA in slime produced by $P$. aeruginosa. 
TABLE 4. The greatest dilution rate ${ }^{a}$ of $5 \%(\mathrm{w} / \mathrm{v})$ chlorhexidine digluconate to kill 11 clinically isolated strains of Pseudomonas aeruginosa as evaluated by the PC test method based on $A O A C$ at $20^{\circ} \mathrm{C}$.

\begin{tabular}{ccccccccc}
\hline \multirow{2}{*}{$\begin{array}{c}\text { Strain } \\
\text { no. }\end{array}$} & \multicolumn{3}{c}{ Cells per ml } & Strain & \multicolumn{3}{c}{ Cells per ml } \\
\cline { 2 - 3 } \cline { 6 - 8 } \cline { 6 - 8 } & $10^{8}$ & $10^{6}$ & $10^{4}$ & no. & $10^{8}$ & $10^{6}$ & $10^{4}$ \\
\hline 2589 & $\times 800$ & $\times 8000$ & $\times 12000$ & 2879 & $\times 1200$ & $\times 4000$ & $\times 12000$ \\
2656 & $\times 400$ & $\times 5000$ & $\times 8000$ & 2882 & $\times 800$ & $\times 6000$ & $\times 10000$ \\
2739 & $\times 400$ & $\times 6000$ & $\times 12000$ & 2892 & $\times 1200$ & $\times 6000$ & $\times 12000$ \\
2740 & $\times 1200$ & $\times 8000$ & $\times 12000$ & 2911 & $\times 1200$ & $\times 6000$ & $\times 10000$ \\
2849 & $N^{b}$ & $\times 6000$ & $\times 8000$ & 3012 & $\times 800$ & $\times 4000$ & $\times 10000$ \\
2853 & $\times 1200$ & $\times 6000$ & $\times 8000$ & & & & \\
\hline
\end{tabular}

${ }^{a}$ Growth of the test organism was evident within 5 min of contact, but not after $10 \mathrm{~min}$.

${ }^{b}$ Not done. This strain did not proliferate even at a cell concentration necessary for the usual cultivation.

There was a big difference in the evaluation of the bactericidal activity of $\mathrm{CHG}$ against $P$. aeruginosa as examined by the two methods. With the modified PC method, the concentration of $\mathrm{CHG}$ able to kill $10^{7}$ cells $/ \mathrm{ml}$ of $P$. aeruginosa in $5 \mathrm{~min}$ was $5000 \mu \mathrm{g} / \mathrm{ml}$, but it was only $25 \mu \mathrm{g} / \mathrm{ml}$ with the PC method based on AOAC. It was reported by Satuta et al. (1983) that the bactericidal activity of $\mathrm{CHG}$ against $P$. aeruginosa was not able to expected. In that report, they adopted the same examination method as the modified PC method. Their method, like ous, also involved adding nine portions of bacterial suspension to one portion of diluted disinfectant. When the volume of bacterial suspension was far larger than the volume of the diluted CHG solution like that in the modified PC method, it seemed that the organism was not sensitized easily by a drug such as $\mathrm{CHG}$.

When the bactericidal activity of the disinfectant is evaluated, the differences in the evaluation caused by examination method used confuse the persons who try to use the disinfectant. Therefore, careful consideration is necessary when the evaluation method of bactericidal activity is newly designed.

\section{ACKNOWLEDGMENTS}

We thank Miss Michiko Abe of Kitasato University Hospital Medical Laboratory for supplying us with many clinical isolates of $P$. aeruginosa. We are also indebted to Dr. Aiko Nakano, formerly of The National Institute of Health, for her technical advice.

\section{REFERENCES}

Engler, R. (1984) Disinfectants. (Sidney, W., ed.), pp.65-69, Official Methods of Analysis of AOAC
Intrernational, Association of Official Analytical Chemists, Inc., Arlington.

Davies, G. E., Francis, J., Martin, A. R., Rose, F. L., and Swain, G. (1954) Laboratory investigation of a new antibacterial agent of high potency. Brit. J. Pharmacol., 9, 192-196.

Goto, S., and Tsuji, A. (1980) Evaluation of disinfectants (in Japanese). Modern Med. Lab., 8, 200206.

Haynes, W. G. (1951) Pseudomonas aeruginosa-its characterization and identification. J. Gen. Microbiol., 5, 935-950.

Jono, K., Uemura, T., Kuno, M., and Higashide, E. (1985) Bactericidal activity and killing rate of benzalkonium chloride and chlorhexidine gluconate (in Japanese). Yakugaku Zasshi, 105, 751-759.

Muto, Y., Kaneko, Y., Tsuji, A., and Goto, S. (1984) Paradoxial effect of slime produced by Pseudomonas aeruginosa on the bactericidal activity of chlorhexidine. Eur. J. Clin. Microbiol., 3, 156158.

Namba, Y., Suzuki, A., Takeshima, N., and Kato, N. (1985) Comparative study of bactericidal activities of six disinfectants. Nagoya J. Med. Sci., 47, 101112.

Satuta, K., Ogawa, M., and Makabe, A. (1983) Bactericidal effect of some disinfectants (in Japanese). J. Nippon Med. Sch., 50, 441-444.

Tsuji, A., Muto, Y., Kaneko, Y., and Goto, S. (1986) Effect of slime produced by Pseudomonas aeruginosa on the bactericidal activity of chlorhexidine (in Japanese). J. J. A. Inf. D., 60, 1324-1333. 